\title{
Computerized Cardiotocography Analysis: Comparison among Several Parental Ethnic Origins
}

\section{Análise de cardiotocografia computadorizada: comparação entre diversas origens étnicas}

\author{
Mariarosaria Di Tommaso ${ }^{1}$ Giulia Martello ${ }^{1}$ Tomi Kanninen ${ }^{1} \quad$ Federica Perelli $^{1} \quad$ Laura lannuzzi $^{1}$ \\ Giovanni Sisti ${ }^{1}$ \\ ${ }^{1}$ Department of Health Sciences, Università degli Studi di Firenze, \\ Firenze, Italy \\ Rev Bras Ginecol Obstet 2016;38:589-592.

\begin{abstract}
Address for correspondence Di Tommaso Mariarosaria, MD, PhD, Department of Health Sciences, Università degli Studi di Firenze, Viale Morgagni 84, 50134, Firenze, Italy

(e-mail: mariarosaria.ditommaso@unifi.it).
\end{abstract}

\begin{abstract}
Keywords

- computerized cardiotocography

- ethnicity

- fetal heart rate

- race
\end{abstract}

\section{Resumo}

Objective We speculate that genetic racial disparity exists in fetal life and can be detected by modern computerized cardiotocography (cCTG).

Methods This is a retrospective study comparing the results of the CCTC of pregnant patients at 37-42 weeks according to the parental ethnicity (black versus white). A CCTG was performed to analyze the variables of fetal heart rate (FHR). The CCTG variables analyzed were: percentage of signal loss; number of contractions; basal FHR; number of accelerations; number of decelerations; length of high variation episodes; short-term variability (STV); total trace duration time; and number of fetal active movements. Non-stress test (NST) parameters in the two groups were compared using the Mann-Whitney test for continuous data, and the Chi-square test for categorical variables.

Results We found a significantly lower number of active fetal movements $(p=0.007)$ and longer periods of low variation $(p=0.047)$ in the CCTG of black patients when compared with white patients.

Conclusions In conclusion, identifying the factors responsible for the variance in the objective analysis of CTG results is important to improve the outcomes of patients. Our study lends further evidence as to the importance of ethnicity in clinical cCTG interpretation.

Objetivo Especulamos que disparidade genética racial exist ana vida do feto, e que possa ser detectada por moderna cardiotocografia computadorizada (cCTG).

Métodos Estudo retrospective comparando resultados do cCTG de gestantes entre 37-42 semanas de gestação de acordo com etnicidade dos pais (negro vs. brancos). CCTG foi usado para analisar as variáveis a frequência cardíaca do feto (FHR). As variáveis abalizadas do CCTG foram o \% de perda de sinal, número de contrações, basal FHR, número de acelerações, número de desacelerações, comprimento dos episódios de alta variação, viabilidade de curto prazo, tempo total de duração do rastreamento, e número received

May 19, 2016

accepted

October 5, 2016

published online

November 22, 2016
DOI http://dx.doi.org/

10.1055/s-0036-1594288. ISSN $0100-7203$.
Copyright $\odot 2017$ by Thieme Publicações License terms

Ltda, Rio de Janeiro, Brazil 


$\begin{array}{ll} & \text { de movimentos de atividade fetal. Os parâmetros do teste de não estresse (NST) em dois } \\ & \text { grupos foram comparados usando o teste de Mann-Whitney para dados contínuos e } \\ & \text { teste qui-square para variáveis categóricas. } \\ \text { Palavras-chave } & \text { Resultados Encontramos números significativamente mais baixos de movimentos de } \\ \text { - cardiotocografia } & \text { atividade fetal }(p=0,007) \text { e períodos mais longos de baixa variação }(p=0,047) \text { no } \\ \text { computadorizada } & \text { cCTG de pacientes negros se comparados a pacientes brancos. } \\ \text { - etnicidade } & \text { Conclusões Identificar fatores responsáveis pela variação na análise objetiva dos } \\ \text { - frequência cardíaca } & \text { resultados de CTG é importante em resultados de pacientes que apresentam melhora. } \\ \text { fetal } & \text { Nosso estudo fornece evidências adicionais à importância de estudos clínicos da } \\ \text { - raça } & \text { etnicidade interpretada pelo cCTG. }\end{array}$

\section{Introduction}

Fetal heart rate (FHR) monitoring has provided the most reliable indicator of fetal wellbeing in clinical practice; however, its control mechanisms are still poorly understood. Cardiotocography (CTG) monitoring of FHR is a noninvasive method that has been augmented recently by advances in computerized CTG (cCTG) analysis, with the latest generation technology superseding past inefficiencies to demonstrate superior results regarding visual analysis. ${ }^{1}$ However, CTG has faced criticism ${ }^{2}$ (due to its high false positive rate), and researchers have suggested that more randomized studies are necessary. ${ }^{3}$ Past studies have also suggested a variability in CTG results with ethnicity. ${ }^{4-6}$

The ethnic origin has been demonstrated as being an independent factor for the development of many clinical conditions, such as hypertension, diabetes, atherosclerosis and coronary heart disease, in newborns, ${ }^{7}$ children, ${ }^{8}$ adolescents ${ }^{9}$ and adults. ${ }^{10}$ Ethnic disparities have also been suggested as a co-factor in many pregnancy complications. ${ }^{11}$ Based on recent projections of the US Census Bureau, the US adult population will gradually become more diverse in the near future, with several different racial or ethnic groups. ${ }^{12}$

Studies dated to more than 10 years ago have demonstrated worse CTG tracings in the fetuses of black women when compared with those of white women. ${ }^{4-6}$

Only a few studies have investigated whether race itself could lead to a bad non-stress test (NST) when excluding all others cofactors. Whether race acted as a surrogate marker for socioeconomic status in these studies remains unclear. The potential biases of these studies are the lack of paternal ethnic origin information, the lack of information on CTG indication, ${ }^{6}$ and the fact that NST reactivity can only be determined visually. ${ }^{4,6}$ The former bias is significant, given the substantial progress CCTG analysis has had over the past 20 years. $^{3}$

The aim of this study was to verify if the maternal and paternal ethnic origins could influence the fetal CCTG in singleton pregnancies, excluding other cofactors.

\section{Methods}

This is a retrospective cross-sectional study comparing the results of the CCTG of pregnant patients at 37-42 weeks in two maternal-fetal medicine centers in northern Italy
(Udine and Pordenone) according to parental ethnicity. The study was approved by the local Ethics Committee, and all the patients provided written consent. The NST was performed on a routine basis after the 37th gestational week, according to the national guidelines. Ethnicity was categorized as black (group B, including all African States, $n=19$ ) and white (group W, including all European States, $n=34$ ). Only pregnant patients with the same ethnicity as their fathers were included in the study. The other inclusion criteria were: singleton pregnancy after week 37 with absence of any maternal and fetal morbidity, such as gestational or pregestational diabetes mellitus; hypertensive disorders of the pregnancy, including preeclampsia, intra-uterine growth retardation (IUGR); and fetal malformation. A cCTG (8002 Sonicaid Fetal Care System, Oxford Sonicaid, UK) was performed to analyze the variables of FHR. The CCTG variables analyzed were: percentage of signal loss; number of contractions; basal FHR; number of accelerations (10-15 bpm and $>15 \mathrm{bpm}$ ); number of decelerations; length of high variation episodes; short-term variability (STV); total trace duration time; and number of fetal active movements. The cCTGs were performed by the midwife/nurse on call, under the supervision of an ob-gyn physician (there were two of them in each of the maternal-fetal medicine centers) with excellent obstetric background training.

Patient data not normally distributed were described as median $\left(25^{\circ}-75^{\circ}\right.$ percentile), whereas variables normally distributed were described as mean (standard error). The Mann-Whitney non parametric test for continuous data and the Chi-square test were used to compare the two groups. A $p$ value $<0.05$ was considered statistically significant. The Statistical Package for Social Sciences (SPSS) software v. 22.0 (IBM, Chicago, Illinois, US) was used for the statistical analysis.

\section{Results}

Nineteen patients were included in group B, and 34 in group W. Groups B and W were matched for maternal age, gestational age, body mass index (BMI), fetal sex and smoking ( - Table 1). Parity was higher in black women ( - Table 1), but this factor is not believed to influence computerized nonstress test (CNST) results. The most representative State of origin in group B was Morocco (37\%), and Italy (76\%) for 
Table 1 Demographic and baseline characteristics of the population

\begin{tabular}{|l|l|l|l|}
\hline & Black $(\boldsymbol{n}=19)$ & White $(\boldsymbol{n}=34)$ & $p$-value \\
\hline Maternal age (years) & 31.2 & 29.7 & 0.861 \\
\hline Gestational age (weeks) & $38[38-40]$ & $39[38-40]$ & 0.759 (Mann-Whitney) \\
\hline BMI $\left(\mathrm{kg} / \mathrm{m}^{2}\right)$ & $26[22.8-27.5]$ & $23[20.1-27.5]$ & 0.073 (Mann-Whitney) \\
\hline Parity & $4=0$ & $\begin{array}{l}18=0 \\
16 \geq 1\end{array}$ & 0.024 (Chi-square) \\
\hline Fetal Sex & $15 \geq 1$ & 17 female, 17 male & 0.854 (Chi-square) \\
\hline Smoker & 9 female, 10 male & $4 / 34$ & 0.120 (Chi-square) \\
\hline Total trace time length (min) & $0 / 19$ & $28.0[14.7-35.7]$ & 0.137 \\
\hline
\end{tabular}

Abbreviation: BMI, body mass index.

group W (data not shown). The trace length was not statistically differently distributed between the two groups (-Table 1).

The perinatal outcomes did not significantly differ between the two groups: the gestational age at delivery was 39.6 years (38.8-40.5 years) in group B, against 39.8 years (38.8-40.6 years) in group W; newborn weight was $3.435 \mathrm{~kg}$ (3.155-3.710) in group B, against $3.460 \mathrm{~kg}$ (3.190-3.750) in group W; the Apgar score at 1 minute was 8.3 (0.1) in group B, against $8.5(0.2)$ in group $W$; and the Apgar score at 5 minute was $9.5(0.1)$ in group B, against $9.6(0.1)$ in group W.

The cNST results when comparing the two groups were the same regarding: percentage of signal loss; number of contractions; basal FHR; number of accelerations (10-15 bpm and $>15 \mathrm{bpm}$ ); number of decelerations; length of high variation episodes; STV; and total trace duration time (-Table 2). The long-term variability was always $>5 \mathrm{bpm}$, and as such, it was not included in the analysis. Statistically significant differences were recorded in number of fetal active movements (20 [8-35] in group B, against 39 [19.2-73.5] in group $\mathrm{W})$ and minutes of low variation $(0[0-11]$ in group $\mathrm{B}$, against 0 in group $\mathrm{W}[0-0]$ ) (-Table 2 ).

\section{Discussion}

In this study we found a significantly lower number of active fetal movements and longer periods of low variation in the cCTG of black patients when compared with white patients.

Paine et $\mathrm{al}^{5}$ were the first to hypothesize that race was a significant co-factor influencing NST results. They conducted the first small prospective study on 100 patients, ${ }^{5}$ and a larger retrospective study later. ${ }^{6}$ In their study, the visual interpretation of the NST was used classifying the trace as reactive or non-reactive. In 1998, Ogueh et $\mathrm{al}^{4}$ conducted a small prospective study with 96 patients. They found significant differences when comparing cCTG in the population groups according to maternal ethnicity. However, the paternal ethnicity was not considered.

Racial differences in the adult population are a well-known risk factor for cardiovascular risk and for heart rate variability. ${ }^{13}$ Recent evidence has suggested that these differences are present only because of the influence of the individual genetic variance, regardless of other cardiovascular factors. ${ }^{14}$ We speculate that the same genetic racial disparity exists in fetal life, and can be detected by modern ultra-sensitive cCTG.

Table 2 Differences in CTG results according to parental ethnicity

\begin{tabular}{|l|l|l|l|}
\hline & Black $(\boldsymbol{n}=19)$ & White $(\boldsymbol{n}=34)$ & $p$ (Mann-Whitney) \\
\hline Signal loss $(\%)$ & $1.6[0.4-3.1]$ & {$[0.075-2.75]$} & 0.132 \\
\hline Number of contractions & $1[0.0-3.0]$ & $1[0-2]$ & 0.886 \\
\hline Fetal active movements (n/h) & $20[8-35]$ & $39[19.2-73.5]$ & 0.007 \\
\hline Basal FHR(bpm) & $137[130-145]$ & $134.5[128-139.5]$ & 0.150 \\
\hline Number of accelerations (10-15 bpm) & $3[1-8]$ & $3.5[1-9]$ & 0.730 \\
\hline Number of accelerations (> 15 bpm) & $3[1-10]$ & $3.5[2-6]$ & 0.181 \\
\hline Number of decelerations & 1 deceleration & 0 decelerations & N/A \\
\hline Length of high variation episodes (min) & $14[1-20]$ & $15.0[10-20.5]$ & 0.788 \\
\hline Length of low variation episodes (min) & $0.0[0-11]$ & $0.0[0-0]$ & 0.047 \\
\hline STV (msec) & $9.4[8.1-13.1]$ & $10.8[9.1-11.6]$ & 0.258 \\
\hline
\end{tabular}

Abbreviations: CTG, Cardiotocography; FHR, fetal heart rate; STV, short-term variability. 
Moreover, this is the first time that the newer generation of cCTG has been adopted to report ethnic differences in a pregnant population. Over the past 20 years, there has been tremendous improvement in this technology, leading to a significant reduction in perinatal mortality. ${ }^{3}$ cCTG can reveal to the physician the fetal heart STV, which cannot be obtained by visual assessment alone. Short-term variability has been shown to be closely related with the fetal wellbeing, and significantly reduced STV is a sign of fetal academia. ${ }^{15-17}$ cCTG significantly lowered perinatal mortality compared with traditional CTG in a selected population, ${ }^{3}$ but to date there are not enough studies supporting the routine use of CTG in all pregnancies, as outlined by a recent meta-analysis.

To our knowledge, this is the first time that both maternal and paternal ethnicities have been considered, and this is one of the strengths of our study. Fetal DNA is equally derived from the contributions of both mother and father. Recently, a study outlined the importance of both parents' ethnicity on the risk of stillbirth in the offspring. ${ }^{18}$ Surprisingly, no prior studies have considered this factor when analyzing the genetic influence on NST readings. ${ }^{4-6}$

We do acknowledge the limitations of our study, primarily the retrospective nature and the low number of patients in each group.

Though the clinical use of the CTG has undoubtedly benefited patients, there remains criticism against its use and reliability, mainly in regard to its false positive rate. Identifying the factors responsible for variance in the objective analysis of CTG results is important to improve the outcomes of patients. Our study lends further evidence as to the importance of ethnicity in clinical cCTG interpretation. Further studies are needed to confirm our finding in a larger population.

\section{Conflicts of interest}

The authors report no conflicts of interest.

\section{References}

1 Dawes GS, Lobb M, Moulden M, Redman CW, Wheeler T. Antenatal cardiotocogram quality and interpretation using computers. $\mathrm{Br} \mathrm{J}$ Obstet Gynaecol 1992;99(10):791-797
2 American College of Obstetricians and Gynecologists. ACOG Practice Bulletin No. 106: Intrapartum fetal heart rate monitoring: nomenclature, interpretation, and general management principles. Obstet Gynecol 2009;114(1):192-202

3 Grivell RM, Alfirevic Z, Gyte GM, Devane D. Antenatal cardiotocography for fetal assessment. Cochrane Database Syst Rev 2015; (9):CD007863

4 Ogueh O, Steer PJ. Ethnicity and fetal heart rate variation. Obstet Gynecol 1998;91(3):324-328

5 Paine LL, Johnson TR, Alexander GR. Auscultated fetal heart rate accelerations. III. Use of vibratory acoustic stimulation. Am J Obstet Gynecol 1988;159(5):1163-1167

6 Paine LL, Strobino DM, Witter FR, Johnson TR. Population differences affect nonstress test reactivity. J Perinatol 1991;11(1):41-45

7 Schachter J, Lachin JM III, Kerr JL, Wimberly FC III, Ratey JJ. Heart rate and blood pressure in black newborns and in white newborns. Pediatrics 1976;58(2):283-287

8 Cheng TL, Goodman E; Committee on Pediatric Research. Race, ethnicity, and socioeconomic status in research on child health. Pediatrics 2015;135(1):e225-e237

9 Wickrama KK, O'Neal CW, Lee TK, Wickrama T. Early socioeconomic adversity, youth positive development, and young adults' cardiometabolic disease risk. Health Psychol 2015;34(9):905-914

10 Mochari-Greenberger H, Mosca L. Differential outcomes by race and ethnicity in patients with coronary heart disease: a contemporary review. Curr Cardiovasc Risk Rep 2015;9(5):20

11 Thomas M, Spielvogel A, Cohen F, et al. Maternal differences and birth outcome disparities: Diversity within a high risk prenatal clinic. J Racial Ethn Health Disparities 2014;1(1):12-20

12 Shrestha LB, Heisler EJ. The changing demographic profile of the United States. Washington (DC): Congressional Research Service; 2011

13 Brondolo E. Racial and ethnic disparities in health: examining the contexts that shape resilience and risk. Psychosom Med 2015; 77(1):2-5

14 Kishi S, Reis JP, Venkatesh BA, et al. Race-ethnic and sex differences in left ventricular structure and function: the Coronary Artery Risk Development in Young Adults (CARDIA) Study. J Am Heart Assoc 2015;4(3):e001264

15 Ribbert LS, Fidler V, Visser GH. Computer-assisted analysis of normal second trimester fetal heart rate patterns. J Perinat Med 1991;19(1-2):53-59

16 Smith JH, Anand KJ, Cotes PM, et al. Antenatal fetal heart rate variation in relation to the respiratory and metabolic status of the compromised human fetus. Br J Obstet Gynaecol 1988;95(10):980-989

17 Turan S, Turan OM, Berg C, et al. Computerized fetal heart rate analysis, Doppler ultrasound and biophysical profile score in the prediction of acid-base status of growth-restricted fetuses. Ultrasound Obstet Gynecol 2007;30(5):750-756

18 Bartsch E, Park AL, Pulver AJ, Urquia ML, Ray JG. Maternal and paternal birthplace and risk of stillbirth. J Obstet Gynaecol Can 2015;37(4):314-323

Authors last names were corrected in this article according to the Erratum published online on March, 2017 (DOI: 10.1055/s-0037-1601338). 